\title{
More on hepatic granulomas
}

\author{
Resat Ozaras,' Mucahit Yemisen and Ilker Inanc Balkan
}

\begin{abstract}
We have read the case report of Nihon-Yanagi et al. The patient they described developed hepatic granuloma two times and the granulomatous lesion was surrounding metal staples/clips suggesting that the granuloma was due to surgical staples/clips.

Hepatic granulomas (HGs) are reported in around $5 \%$ of patient who undergo a liver biopsy and caused by several diseases including sarcoidosis, tuberculosis, hydatid cyst, brucellosis, typhoid fever, chronic hepatitis B and C and primary biliary cirrhosis (PBC). Chronic hepatitis B and C infections are the most common and serious causes of liver damage in patient with renal failure. Their prevalence is a higher than people without renal failure. We have previously reported that the prevalences of HGs in patients with chronic hepatitis B and C are 1.5 and $1.3 \%$ respectively. The described patient was on hemodialysis for 12 years. The other causes of HG seem excluded; however hepatitis B and C infections and PBC should have been tested and excluded before ascribing the HGs to surgical staples/clipping material.
\end{abstract}

Keywords: Hepatic granuloma, Surgical staples, Chronic hepatitis

\section{Letters to the Editor}

Dear Sir,

We have read the case report of Nihon-Yanagi et al. [1] with great interest. The patient they described developed hepatic granuloma(HG) two times and the granulomatous lesion was surrounding metal staples/clips suggesting that the granuloma was due to surgical/staples/clips.

HGs are reported in around $5 \%$ of patient who undergo a liver biopsy and caused by several diseases including sarcoidosis, tuberculosis, hydatid cyst, brucellosis, typhoid fever, chronic hepatitis $\mathrm{B}$ and $\mathrm{C}$, and primary biliary cirrhosis $(\mathrm{PBC})[2,3]$. Chronic hepatitis $\mathrm{B}$ and $\mathrm{C}$ infections are the most common and serious causes of liver damage in patients with renal failure [4]. Their prevalence is a higher than people without renal failure. We have previously reported that the prevalences of HGs in patients with chronic hepatitis $B$ and $C$ are 1.5 and $1.3 \%$ respectively $[5,6]$. The described patient was on hemodialysis for 12 years.

Another cause of HBs is PBC. It is an immunemediated cholestatic liver disease characterized by destruction of cholangiocytes. The histology includes a portal tract inflammatory infiltrate composed of plasma

\footnotetext{
* Correspondence: rozaras@yahoo.com

Infectious Diseases Department, Cerrahpasa Medical School, Istanbul University, TR-34098 Cerrahpasa, Istanbul, Turkey
}

cells, mononuclear cells, and neutrophils [7]. Noncaseating epithelioid granulomas are seen especially in early-stage disease. The diagnosis is made by the presence of the antimitochondrial antibody which is found in $95 \%$ of patients.

In chronic liver disease and $\mathrm{PBC}$, the described granulomas are microscopic granulomas and the ones in the presented case are macroscopic granulomas. However it is not known whether the causes of microscopic granulomas may also cause macroscopic granulomas or contribute to the development of macroscopic granulomas of any other causes.

The other causes of HG seem excluded; however hepatitis $\mathrm{B}$ and $\mathrm{C}$ infections and $\mathrm{PBC}$ should have been tested and excluded before ascribing the HGs to surgical staples/clipping material.

\section{Abbreviations}

HG: Hepatic granulomas; PBC: Primary biliary cirrhosis.

\section{Competing interest}

The authors declare that they have no competing interests.

\section{Authors' contribution}

$\mathrm{RO}$ designed and wrote the manuscript. IIB and MY reviewed the literature, acquired data and helped to draft the manuscript. All authors read and approved the final manuscript.

Received: 8 September 2015 Accepted: 12 November 2015 Published online: 19 November 2015 


\section{References}

1. Nihon-Yanagi Y, Ishiwatari T, Otsuka Y, Okubo Y, Tochigi N, Wakayama M, et al. A case of postoperative hepatic granuloma presumptively caused by surgical staples/clipping materials. Diagn Pathol. 2015;10:90. doi:10.1186/s13000-015-0291-3.

2. Mert A, Ozaras R, Bilir M, Tahan V, Cetinkaya A, Yirmibescik S, et al. The etiology of hepatic granulomas. J Clin Gastroenterol. 2001;32(3):275-6.

3. Mert A, Tabak F, Ozaras R, Ozturk R, Aki H, Aktuglu Y. Typhoid fever as a rare cause of hepatic, splenic, and bone marrow granulomas. Intern Med. 2004; 43(5):436-9.

4. Fabrizi F, Messa P, Basile C, Martin P. Hepatic disorders in chronic kidney disease. Nat Rev Nephrol. 2010;6(7):395-403.

5. Tahan V, Ozaras R, Lacevic N, Ozden E, Yemisen M, Ozdogan O, et al. Prevalence of hepatic granulomas in chronic hepatitis B. Dig Dis Sci. 2004; 49(10):1575-7.

6. Ozaras R, Tahan V, Mert A, Uraz S, Kanat M, Tabak F, et al. The prevalence of hepatic granulomas in chronic hepatitis C. J Clin Gastroenterol. 2004;38(5): 449-52.

7. You Z, Wang Q, Bian Z, Liu Y, Han X, Peng Y, et al. The immunopathology of liver granulomas in primary biliary cirrhosis. J Autoimmun. 2012;39(3): 216-21

\section{Submit your next manuscript to BioMed Central and take full advantage of:}

- Convenient online submission

- Thorough peer review

- No space constraints or color figure charges

- Immediate publication on acceptance

- Inclusion in PubMed, CAS, Scopus and Google Scholar

- Research which is freely available for redistribution 